\title{
Trampling Intensity and Vegetation Response and Recovery according to Altitude: An Experimental Study from the Himalayan Miyar Valley
}

\author{
Michal Apollo ${ }^{1, *(\mathbb{D})}$ and Viacheslav Andreychouk ${ }^{2}$ \\ 1 Department of Tourism and Regional Studies, Institute of Geography, Pedagogical University of Cracow, \\ Podchorazych Street 2, 30-084 Cracow, Poland \\ 2 Faculty of Geography and Regional Studies, University of Warsaw, Krakowskie Przedmiescie 30, \\ 00-927 Warsaw, Poland \\ * Correspondence: michal.apollo@up.krakow.pl or apollomichal@gmail.com
}

Received: 21 July 2020; Accepted: 10 August 2020; Published: 17 August 2020

\begin{abstract}
The trampling of vegetation caused by recreation and tourism can lead to the loss of vegetation and the degradation of plant communities, which adversely affects natural habitats. This paper investigates the impact of trampling on plant species in the high-mountain environment, where plant resources are limited and any recovery is slow. It is commonly accepted that the sensitivity of the vegetation in mountains increases as altitude increases. Therefore, this study supposed that the same plant species would have different responses to trampling at different altitudes. By using a standardized method of experimental trampling, an empirical study was conducted on eight plant species at two altitudes: $4072 \mathrm{~m}$ and $4480 \mathrm{~m}$. Each species was trampled 0-500 times. Response to trampling was assessed by determining plant cover two weeks after trampling and one year after trampling. For most species, the relationship between plant cover after trampling and trampling intensity was very clear (linear). This research found the following: (1) vegetation has extremely high ecological sensitivity to trampling in the examined environment; (2) above $4000 \mathrm{~m}$, an increase in altitude does not increase the sensitivity of vegetation. Vegetation above a certain altitude exhibits similar, very high sensitivity to trampling.
\end{abstract}

Keywords: altitude; high-mountain environment; recreation impact; trampling; trails; vegetation impact

\section{Introduction}

Even in the first studies on the ecological consequences of tourism, the topic of changes to vegetation cover was dominant [1,2]. Pressure on vegetation from tourism may reduce the size, stem height, leaf area, and number of flowers, and thus seed production of plants [3]. These changes lead to reduced viability, less successful reproduction, and consequently to the death of some less-resistant plant species, especially in the rough environments [4,5]. For example, tundra vegetation that has been damaged for only a few seasons will require hundreds of years to recover or will never be recovered [6]. Plant destruction has a serious consequence: it can adversely impact natural habitats, leading to the loss of vegetation and eventually ground degradation [7-10]. What is more, the impact of tourists contributes to increased trampling and tearing, as well as the displacement of the vegetation and soil cover in the immediate vicinity of the footpaths, and leads to erosion $[7,10-13]$.

Sensitive to outside influences, the environment of high mountain areas, until recently cut off from civilization, has been abruptly exposed to mountaineering activity [14]. Mountaineering, broadly defined as hiking, trekking, and climbing, is nowadays a mass phenomenon [15-17], and numerous studies have shown that the growth rate of mountain-based adventure tourism 
has increased dramatically in recent decades [16,18,19]. Increasing tourism touches every element of the very fragile high-mountain environment [20]. At the same time, managing agencies are asked to simultaneously preserve natural conditions and allow for recreational use of these areas [21]. An optimal balance between these competing goals is possible to maintain only if tourism and environmental conservation stay in a win-win situation, i.e., a symbiotic stage [22]. Thus, land managers need better information about the recreational impacts on the environment [21]. The high-mountain environment is very sensitive to any changes, but as Apollo and Andreychouk [14] showed, the balance of environmental profit and loss depends on a number of factors and circumstances. However, even that fragile environment may deal with the negative effects of a visitor's activity without any problems.

Overall, due to diversification, commodification, and commercialization, mountaineering is becoming more mass tourism than elite [16], and recently, the boundaries between mountaineering and tourism are increasingly blurred in mountains throughout the world, and more and more mountain tourists climb/trek higher and higher. The environment of high mountain areas has clearly been affected. That is why it is important to check the mountaineers' impact in this very fragile environment. Thus, the right management tools are essential.

This study focuses on changes to vegetation cover caused by trampling. Most of the researchers describing vegetation transformations use experimental methods that examine the relationship between the intensity of tourism (trampling) and the response of vegetation $[23,24]$. This approach is used in Wagar's [25] early work and in the more recent papers of Cole [21,26] and Hill and Pickering [13]. Initially, most studies regarding the relationship between tourism and vegetation concentrated on mountains [23]; later, numerous studies analyzed vegetation trampling resulting from outdoor recreation on various areas $[24,27,28]$. However, only a few studies focused on the high-mountain environment [4,11,29-32], and these studied a maximum altitude of $4270 \mathrm{~m}$ [33].

Pescott and Stewart's [24] review (upgraded by the authors) reported that the responses of vegetation to trampling are affected by the following: trampling intensity (number of human trampling passes [21,34,35]), frequency (trampling passes per time period [36]), distribution (whether trampling passes are dispersed or clumped for a particular trampling frequency [37]), weight of broken biomass [35], season [38], weather [39], habitat [33,40], species [35-37], Raunkiaer life-form (i.e., perennating bud position) and growth-form [26], soil type [41], and surface profile [35]. However, their review does not mention altitude.

Already, Humboldt [42] and Darwin [43] mentioned that the sensitivity of the environment increased as altitude increased. Today, altitudinal zonation represents a core concept in research on the mountain environment. Nevertheless, the amount of works analyzing changes in the sensitivity (or susceptibility) of biotic elements in mountain landscapes to anthropogenic impact in relation to a change in altitude is negligible. Up until today, only one study has investigated the effect of trampling according to different altitudes. Chardon et al. [33] noted that at lower, warmer altitudes, trampling reduces the amount of competing vegetation and increases habitat availability, exerting a net positive impact on cushion plant performance. In turn, at higher elevations, which are colder and likely have fewer biotic interactions, disturbance has a neutral or net negative impact on cushion plants.

Based on the above, this paper seeks an answer to two questions: (1) What is the level of vegetation response to trampling at the altitudes of 4072 and $4480 \mathrm{~m}$ ? (2) How is this response different at the two altitudes, assuming that exactly the same plant species have been trampled?

The study was conducted in the Indian Miyar Valley (Lahaul Himalaya). The research reported in this paper used the method standardized by Cole and Bayfield [29]: experimental trampling was done in two polygons (with eight different plant species) located at the altitudes of 4072 and $4480 \mathrm{~m}$. 


\section{Study Area and Research Methodology}

The experimental research was conducted in the Miyar Valley (Figure 1), in the division of Punjab Himalaya. The valley is part of the Lahoul Range, located between the Pir Panjal and Zanskar Ranges. The valley is nearly $75 \mathrm{~km}$ long and stretches between Udaipur (at the mouth of the valley, $2649 \mathrm{~m}$ ) and the Kang La pass $(5468 \mathrm{~m})$. More than $50 \%\left(568 \mathrm{~km}^{2}\right)$ of the Miyar Valley area $\left(975.7 \mathrm{~km}^{2}\right)$ is covered with glaciers [44]. Average temperatures and precipitation in the Miyar Valley vary widely: for Udaipur $(2649 \mathrm{~m})$, these values are $9.4{ }^{\circ} \mathrm{C}$ and $1057 \mathrm{~mm}$; for Sucto village $(3448 \mathrm{~m}), 5{ }^{\circ} \mathrm{C}$ and $605 \mathrm{~mm}$; and in the higher parts (alpine and nival zones), the average annual temperature always stays below $0{ }^{\circ} \mathrm{C}$ [45]. According to Saini [46], the soil of the Miyar Valley can be classified into three types: Himalayan alluvial soils, mountain and hill soils, and high-altitude meadow soils. Since the 1970s, the Miyar Valley has been under the influence of small-scale tourism [47,48], and in 2012, approximately 700 people visited the valley [47].
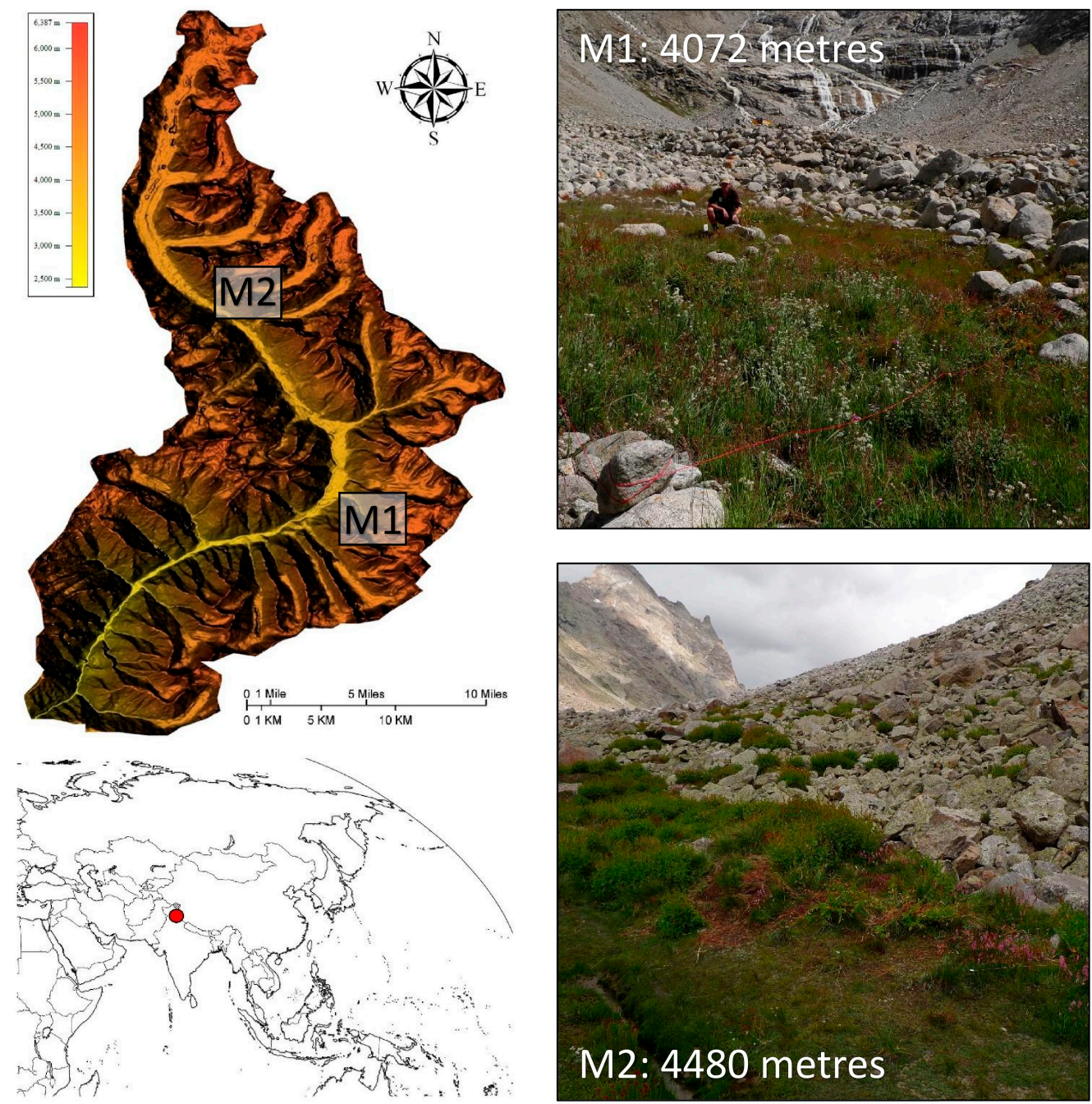

Figure 1. Location of research plots in the Miyar Valley used for experimental trampling of vegetation.

The methodology used to research vegetation trampling has evolved over the years, e.g., the length and width of polygons and the number of passes used for the experimental trampling have changed. To enable results of experimental trampling from different parts of the world to be compared, Cole and Bayfield [29] unified the methodology. Their guidelines have been used in this study.

Two research plots were designated in the Miyar Valley (Figure 1): M1 (4072 m) and M2 (4480 m). Five lanes of $150 \times 50 \mathrm{~cm}$ were created at each research plot (Figure 2). Four lanes were then subjected 
to different amounts of trampling: 25, 75, 200, and 500 passes. One was left untouched as a control area (no trampling) (Figure 3). Lanes were randomly assigned the amount of trampling they would receive. The trampling passes were made in one direction according to the natural downward slope. The person doing the trampling weighed about $80 \mathrm{~kg}$ and was equipped with mountain shoes with a grooved sole (Vibram Carrarmato).
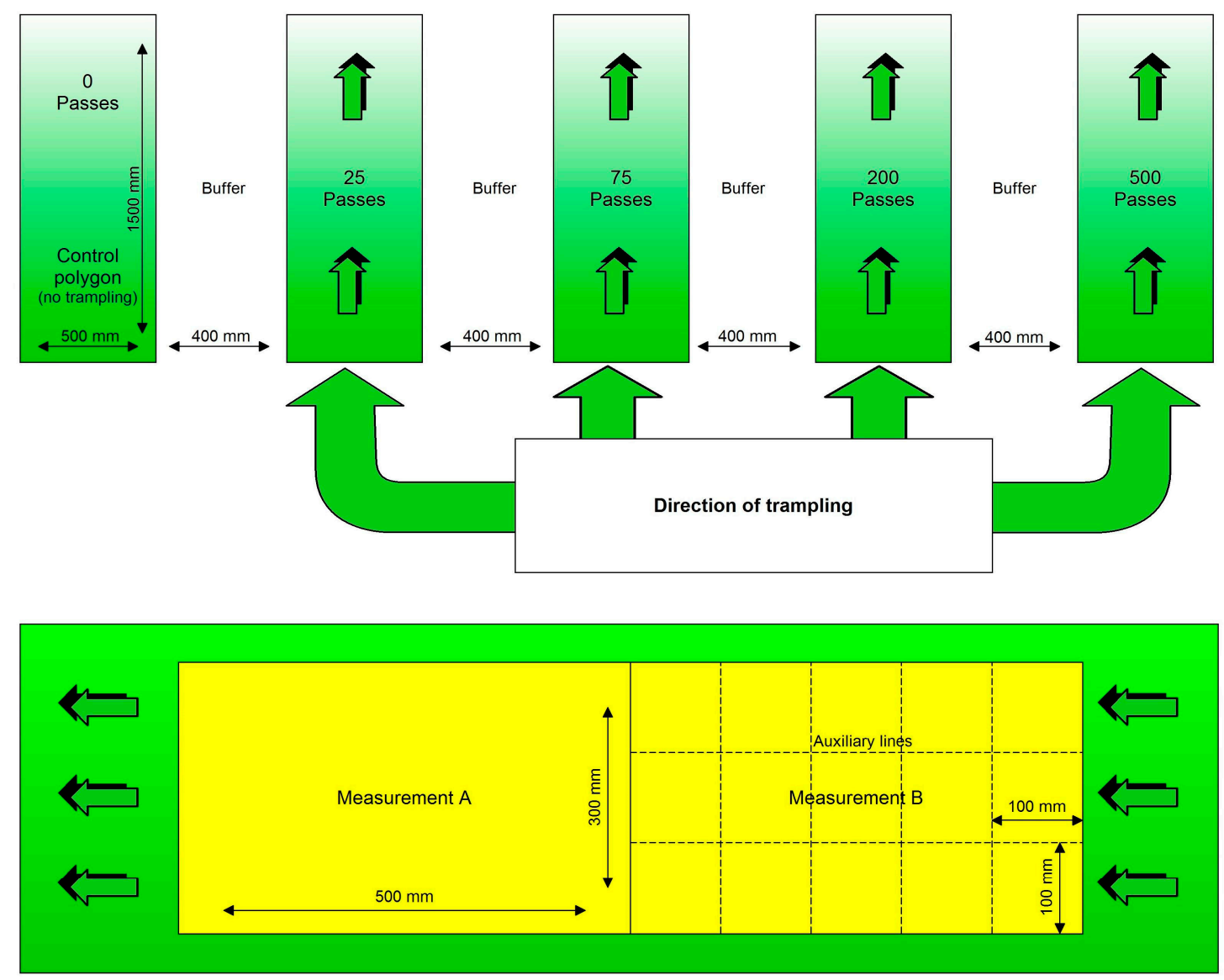

Figure 2. Experimental trampling of vegetation: layout of test strips within the experimental trampling lanes and subplots within the test strips.

Two smaller plots $(50 \mathrm{~cm} \times 30 \mathrm{~cm}$; A and B) within each experimental trampling lane were used as test strips. To facilitate measurement reading, the test strips (A and B) were divided into smaller subplots $(100 \mathrm{~cm} \times 100 \mathrm{~mm})$. In each subplot, the cover of each plant species was estimated (Figure 2), and the received data were converted into percentage values. The number of plants was measured before the trampling process and two weeks and one year after trampling (Figure 3).

In order to estimate the quantitative change, i.e., changes in the number of plants of individual species, the number of plants of a given persistent species that existed after the trampling process (after two weeks and one year) was compared to the number occurring before the trampling, taking into account the correlation factor (F) for changes in the controls in order to separate the effects of trampling from other factors that affect change [21]. This is known as relative vegetation cover and was calculated by summing the cover of each individual species to obtain total cover, and then calculating the percentage of original vegetation that survived trampling, adjusted for changes in the controls. The calculation was made using the following formula (Equation (1)):

$$
\frac{\text { surviving cover on trampled subplot }}{\text { initial cover on trampled subplot }} \times \mathrm{F} \times 100 \%
$$


where:

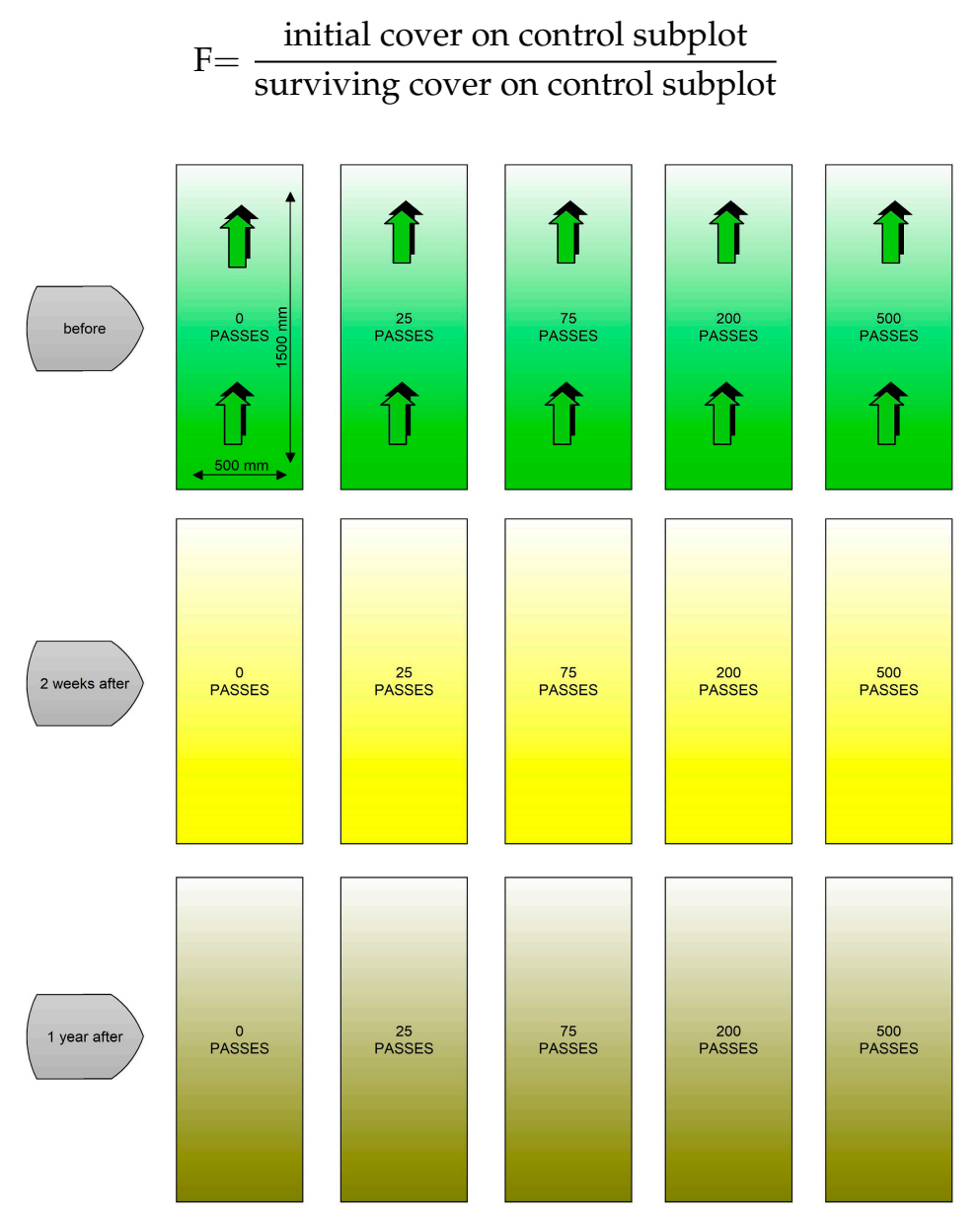

Figure 3. Experimental trampling of vegetation: measurement reading procedure.

Eight plant species commonly found in the Himalayan Miyar Valley were selected for the study (Figure 4). Six of them were found at both research plots. All species were perennial (living for more than two years) vascular plants (Tracheophyta)-precisely hardy perennial (Herba perennis): Corydalis govaniana, Potentilla argyrophylla, Pedicularis bicornuta, Persicaria affinis, Rhodiola heterodonta, Rhodiola fastigiata, Aconogonum rumicifolium, and Anaphalis nepalensis. Morphological plant features were described based on Flowers of the Himalaya by Polunin and Stainton [49].

The results were analyzed by comparing the change in cover of each species when subjected to trampling and the intensity of this change in relation to the trampling frequency. This was recorded in the form of regression models. The change in cover of the six plant species found at both research plots was also compared for the two different altitudes: $4072 \mathrm{~m}$ (M1) and $4480 \mathrm{~m}$ (M2). 


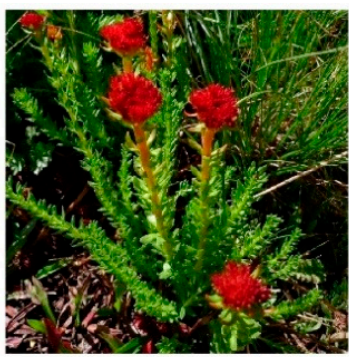

Rhodiola fastigiata

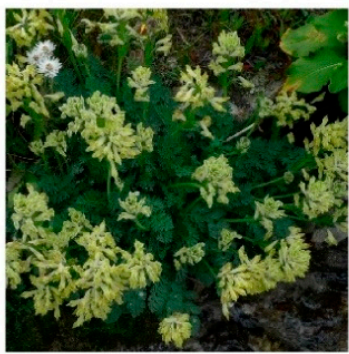

Corydalis govaniana

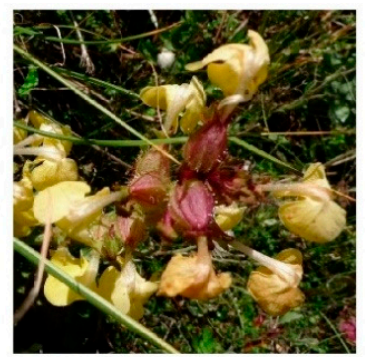

Pedicularis bicornuta

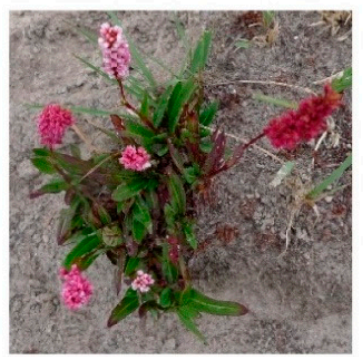

Persicaria affinis

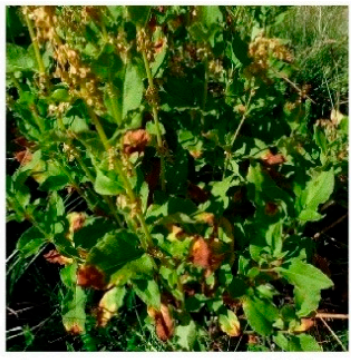

Aconogonum rumicifolium

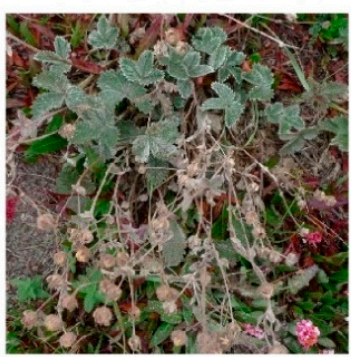

Potentilla argyrophylla

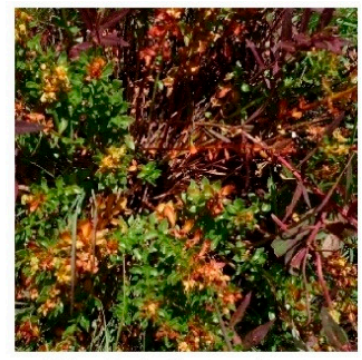

Rhodiola heterodonta

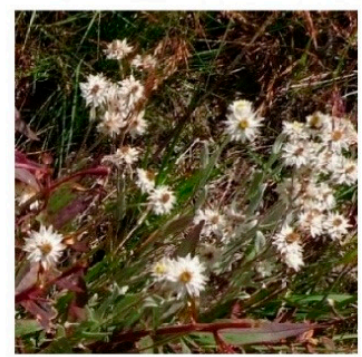

Anaphalis nepalensis

Figure 4. Plants exposed to experimental trampling in the Miyar Valley at the M1 and M2 research plots.

\section{Results}

\subsection{Variation in Vegetation Response to Trampling}

Of the studied plants, Persicaria affinis showed the highest resistance to trampling (Figure 5). This plant is a semi-cold green perennial forming turf with dark green leaves (about 10-15 cm) and often woody stems reaching 20-25 cm in length. Dense dark pink or red flowers appear in the upper part of the stem. This plant was found to survive even if its aerial part was completely destroyed. Glands, and at a later stage, woody stems and hardy leaves were virtually resistant to trampling. On both research plots, there was an average of a $25 \%$ (fast) decrease in the population after 25 and 75 passes. More trampling —even 500 passes - did not cause losses higher than $18-33 \%$ in the period of two weeks after trampling. Unfortunately, the initial (two weeks after trampling) high resistance to trampling was not confirmed after a period of one year. Persicaria affinis plants were from $43 \%$ (M2) to $69 \%$ (M1) less.

Aconogonum rumicifolium, Rhodiola fastigiata, and Corydalis govaniana showed a very similar, moderate reaction to trampling (Figure 5). All species showed a rapid decrease in the number of plants after 75 passes, but above this number of passes, further decrease was small. There was a high correlation between plants of these species that survived after two weeks with those that survived after one year. However, two weeks after 500 passes, the population of these plants fell by three-quarters. One year after 500 passes, only individual plants from these species were noted (an average of about $10 \%$ of the original populations in both research plots).

There was no correlation between cover of Anaphalis nepalensis and Potentilla argyrophylla (except Potentilla argyrophylla from M2) recorded two weeks after trampling and after one year (Figure 5). After a period of two weeks, the number of individual plants remained practically the same after 25 passes as before trampling. The number of surviving plants decreased moderately after 75 passes and fell to $21-33 \%$ for Potentilla argyrophylla (0-4\% for Anaphalis nepalensis) after 500 passes. After a period of one year in the lanes where 200 passes had been made, these plants either did not exist or were reduced to several percent. 
M1: 4078 metres
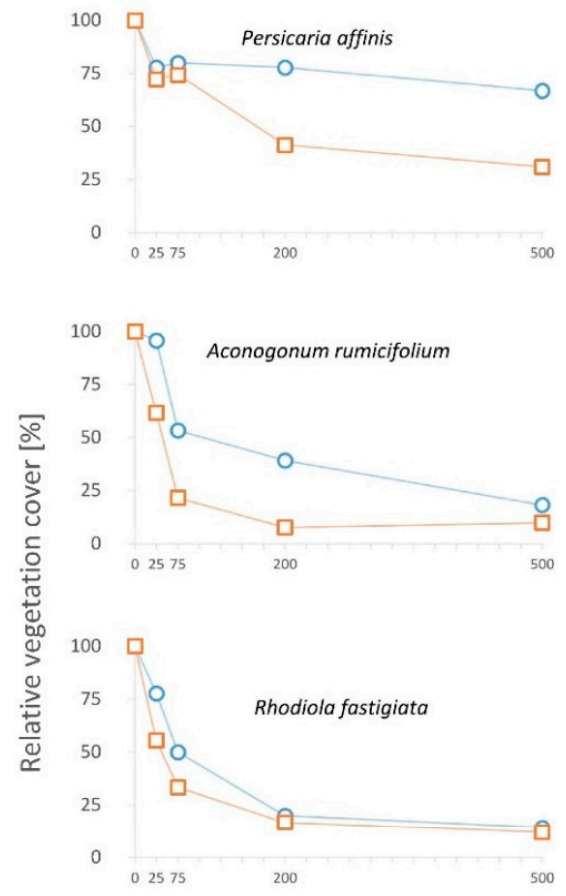

Species not present
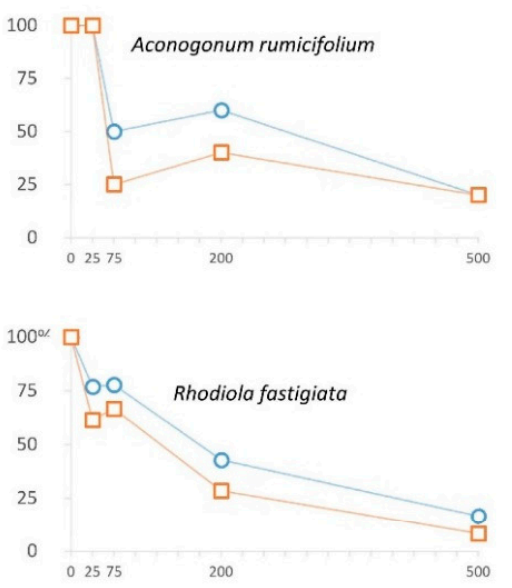

M2: 4480 metres
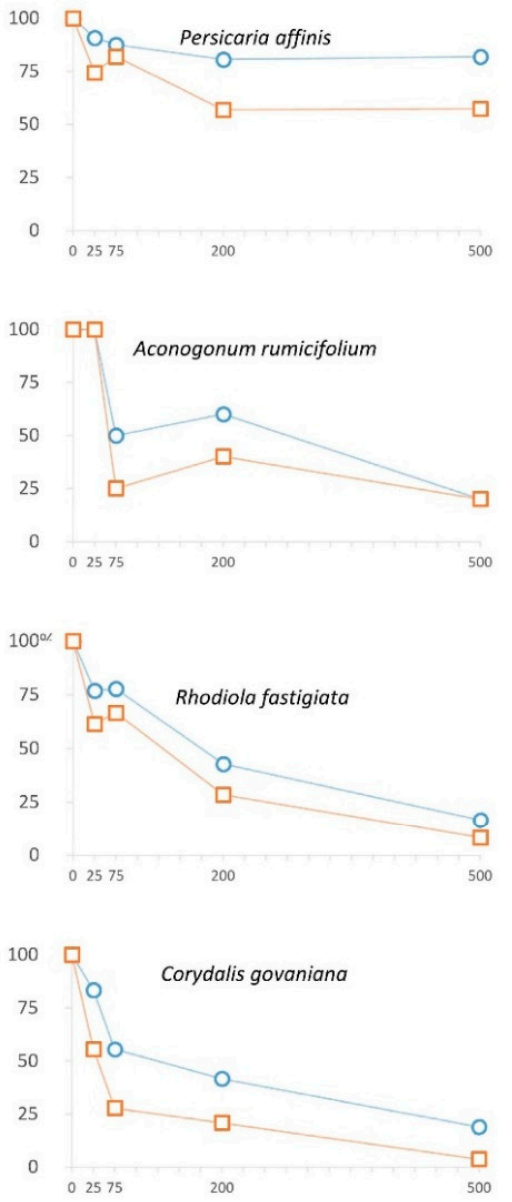

M1: 4078 metres
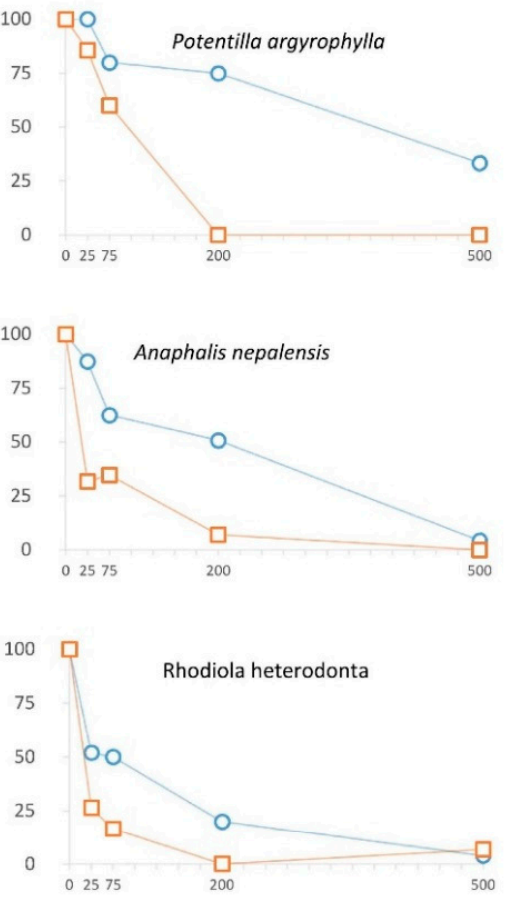

Species not present
M2: 4480 metres
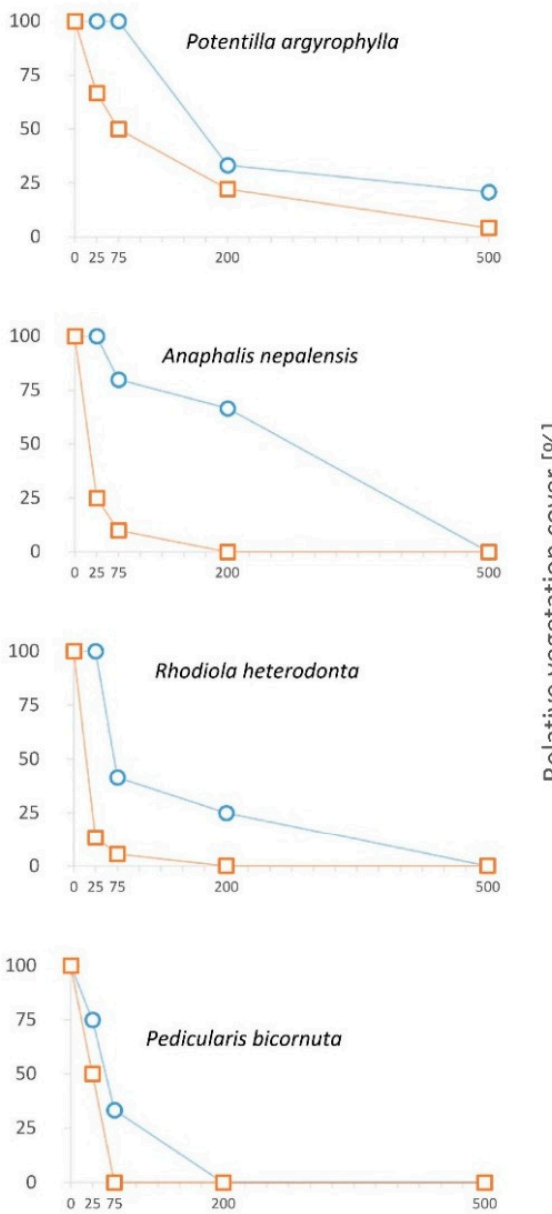

Number of passes

Figure 5. Correlation between trampling intensity (x-axis) and relative vegetation cover (y-axis) two weeks after trampling $(\bigcirc)$ and one year after trampling ( $\square$ ) for each of the six vegetation types in M1 and eight in M2. Types are arranged from those that lost the least cover after trampling to those that lost the most. 
Pedicularis bicornuta and Rhodiola heterodonta showed the lowest resistance to trampling. In both cases, tall, slender, and fragile stems were extremely sensitive to fracturing. This was confirmed with the test results. Pedicularis bicornuta was completely eliminated after 200 passes two weeks after trampling, but more importantly, 75 passes were enough to prevent the plant from appearing after a year. After only 25 passes, the population of Pedicularis bicornuta decreased by $25 \%$ two weeks after trampling and by as much as 50\% one year after trampling. Rhodiola heterodonta was not much more resistant. Two weeks after 25 passes, the Rhodiola heterodonta population was reduced by 59\% (M1) and $48 \%$ (M2), and by $87 \%$ (M2) and 74\% (M1) after one year. It should be noted, however, that several plants $(7 \%)$ appeared after a year at M1, which may indicate perennial survival or germination of new plants.

\subsection{Regression Models of Vegetation Response to Different Amounts of Trampling}

Based on the results of the research, regression models were developed to estimate the relationship between the intensity of trampling and the response of individual plant species. To determine which model described the collected data best and most simply, the coefficient of determination $\left(\mathrm{R}^{2}\right)$ was used. Generally, the higher the value of $\mathrm{R}^{2}$, the better the model depicts reality. After analysis of linear functions and curves, the linear function was found to be most appropriate for showing the relationship between trampling and vegetation response in our study (Table 1).

Table 1. Regression models that approximate the correlation between trampling intensity $(x=$ number of passes) and destruction of vegetation (y). Separate models are given for two weeks after trampling and one year after trampling for two research plots (M1 and M2).

\begin{tabular}{|c|c|c|c|c|c|}
\hline \multirow{2}{*}{ Species } & \multirow{2}{*}{$\begin{array}{l}\text { Research } \\
\text { Plot }\end{array}$} & \multicolumn{2}{|c|}{ Two Weeks After Trampling } & \multicolumn{2}{|c|}{ One Year After Trampling } \\
\hline & & Linear Regression Model & $\mathbf{R}^{2}$ & Linear Regression Model & $\mathbf{R}^{2}$ \\
\hline \multirow{2}{*}{$\begin{array}{l}\text { Persicaria } \\
\text { affinis }\end{array}$} & M1 & $y=-0.0447 x+87.598$ & 0.5732 & $y=-0.1182 x+82.661$ & 0.7639 \\
\hline & M2 & $y=-0.0274 x+92.569$ & 0.5218 & $y=-0.0669 x+84.822$ & 0.574 \\
\hline \multirow{2}{*}{$\begin{array}{l}\text { Aconogonum } \\
\text { rumicifolium }\end{array}$} & M1 & $y=-0.1528 x+85.733$ & 0.771 & $y=-0.1337 x+61.511$ & 0.4731 \\
\hline & M2 & $y=-0.1459 x+89.346$ & 0.7589 & $y=-0.138 x+79.086$ & 0.5025 \\
\hline \multirow{2}{*}{$\begin{array}{l}\text { Rhodiola } \\
\text { fastigiata }\end{array}$} & M1 & $y=-0.1491 x+76.276$ & 0.6907 & $y=-0.1285 x+64.052$ & 0.5384 \\
\hline & M2 & $y=-0.1522 x+87.204$ & 0.8999 & $y=-0.1545 x+77.745$ & 0.7938 \\
\hline \multirow{2}{*}{$\begin{array}{l}\text { Corydalis } \\
\text { govaniana }\end{array}$} & M1 & \multicolumn{4}{|c|}{ not present } \\
\hline & M2 & $y=-0.1418 x+82.596$ & 0.8087 & $y=-0.1411 x+64.168$ & 0.5921 \\
\hline \multirow{2}{*}{$\begin{array}{l}\text { Anaphalis } \\
\text { nepalensis }\end{array}$} & M1 & $y=-0.176 x+89.187$ & 0.9411 & $y=-0.1365 x+56.569$ & 0.5025 \\
\hline & M2 & $y=-0.1999 x+101.32$ & 0.9874 & $y=-0.3684 x+61.382$ & 0.5226 \\
\hline \multirow{2}{*}{$\begin{array}{l}\text { Potentilla } \\
\text { argyrophylla }\end{array}$} & M1 & $y=-0.1306 x+98.557$ & 0.9638 & $y=-0.4962 x+98.645$ & 0.9992 \\
\hline & M2 & $y=-0.1758 x+98.966$ & 0.8054 & $y=-0.1601 x+74.235$ & 0.765 \\
\hline \multirow{2}{*}{$\begin{array}{l}\text { Pedicularis } \\
\text { bicornuta }\end{array}$} & M1 & \multicolumn{4}{|c|}{ not present } \\
\hline & M2 & $y=-0.4737 x+87.609$ & 0.9054 & $y=-1.2857 x+92.857$ & 0.9643 \\
\hline \multirow{2}{*}{$\begin{array}{c}\text { Rhodiola } \\
\text { heterodonta }\end{array}$} & M1 & $y=-0.1496 x+69.114$ & 0.6949 & $y=-0.111 x+47.688$ & 0.3171 \\
\hline & M2 & $y=-0.1903 x+83.749$ & 0.7485 & $y=-0.3439 x+55.511$ & 0.4207 \\
\hline
\end{tabular}

The accuracy of the models was checked using factor $\varphi^{2}\left(\varphi^{2}=1-R^{2}\right) \cdot \varphi^{2}$ illustrates how much of the variation in the variable (in this case, loss of vegetation cover under the influence of an appropriate number of passes) is not explained by the model. The obtained values of $\varphi^{2}$ in most cases indicate a good fit of the model. In general, the fit of the model is better the closer the value of $\varphi^{2}$ is to 0 .

The tendency for changes in the population of the studied plants under the influence of an increasing trampling intensity is best and most simply described by a linear function. This is perfectly visible in the graphs of Figure 5, where, looking at the trend (0-500 passes), one can easily see their linear change (Figure 6). 


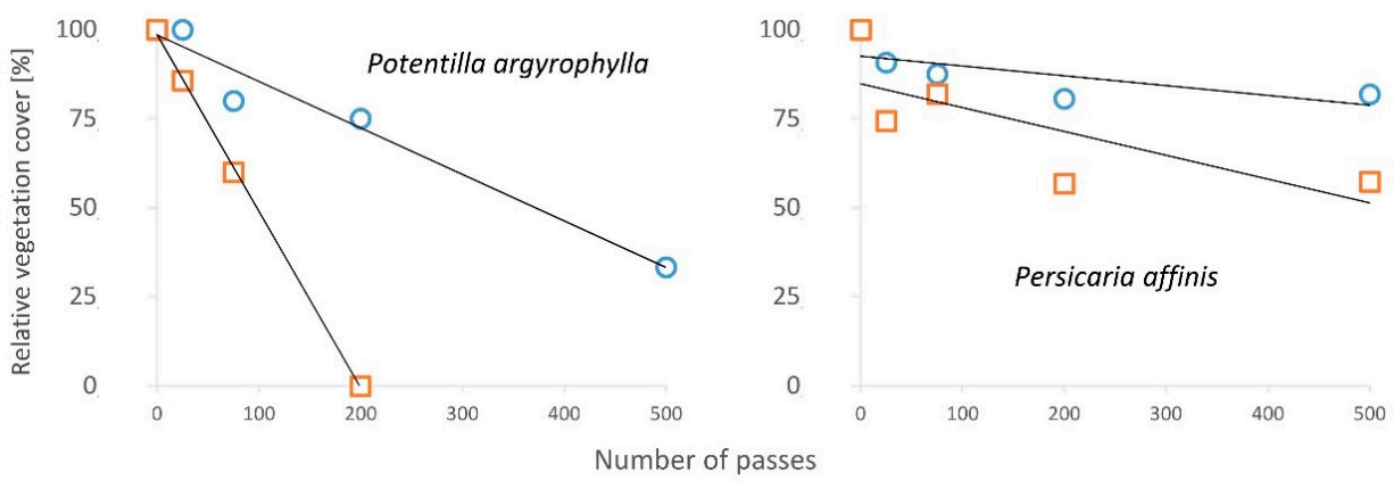

Figure 6. The best-fitting linear model for Potentilla argyrophylla (M1) and the worst for Persicaria affinis (M2) according to $\varphi^{2}$.

It can be easily noted that the linear model, even for Persicaria affinis (low model fit: $\varphi^{2}=0.43-0.48$ ), correctly presents the direction of change of vegetation cover. However, for many plant species, the linear model does not show the correct rate of change (25-200 and 200-500 passes). Looking at the destruction of Rhodiola fastigiata or Aconogonum rumicifolium, it can be concluded that they are described much better by a curvilinear tendency of change. In these cases, modelling the effect of trampling on vegetation should be shown with more complex models.

\subsection{Changes in Vegetation Cover Due to Trampling at Various Altitudes}

Table 2 presents a comparison of the change in plant cover for each species at M1 (4072 m) and M2 (4480 m)-a difference in altitude of approximately $400 \mathrm{~m}$. The comparison was made using the mean change and the Pearson correlation coefficient. The mean change represents the mean percentage change in the amount of plant cover for the change in altitude (negative values indicate less cover after trampling at a higher altitude, positive values indicate more cover). The Pearson correlation coefficient shows the relationship between variables at different heights.

Table 2. Correlation between change in plant cover due to trampling and altitude (mean change and Pearson correlation coefficient).

\begin{tabular}{|c|c|c|c|}
\hline \multirow[b]{2}{*}{ Species } & \multirow[b]{2}{*}{ Coefficient } & $\begin{array}{c}\text { Two Weeks After } \\
\text { Trampling }\end{array}$ & $\begin{array}{l}\text { One Year After } \\
\text { Trampling }\end{array}$ \\
\hline & & $\begin{aligned} \mathrm{M} 1 & \rightarrow \mathrm{M} 2 \\
(4072 \mathrm{~m}) & \rightarrow(4480 \mathrm{~m})\end{aligned}$ & $\begin{aligned} \mathrm{M} 1 & \rightarrow \mathrm{M} 2 \\
(4072 \mathrm{~m}) & \rightarrow(4480 \mathrm{~m})\end{aligned}$ \\
\hline \multirow{2}{*}{ Persicaria affinis } & Mean change $(\%)$ & -9.67 & -12.96 \\
\hline & Pearson correlation coefficient & 0.49 & 0.96 \\
\hline \multirow{2}{*}{ Aconogonum rumicifolium } & Mean change $(\%)$ & 24.53 & 12.64 \\
\hline & Pearson correlation coefficient & 0.96 & 0.97 \\
\hline \multirow{2}{*}{ Rhodiola fastigiata } & Mean change $(\%)$ & -13.04 & -11.91 \\
\hline & Pearson correlation coefficient & 0.88 & 0.83 \\
\hline \multirow{2}{*}{ Anaphalis nepalensis } & Mean change $(\%)$ & -10.39 & 9.67 \\
\hline & Pearson correlation coefficient & 0.99 & 0.81 \\
\hline \multirow{2}{*}{ Potentilla argyrophylla } & Mean change $(\%)$ & 8.54 & 0.66 \\
\hline & Pearson correlation coefficient & 0.80 & 0.96 \\
\hline \multirow{2}{*}{ Rhodiola heterodonta } & Mean change $(\%)$ & -10.14 & 7.69 \\
\hline & Pearson correlation coefficient & 0.85 & 0.96 \\
\hline
\end{tabular}

The high correlation (0.84-0.99) of the direction and scale of changes indicates a relatively small relationship between vegetation response and increase in altitude. Individual plants, regardless of the 
difference in altitude between the research plots, reacted very similarly to trampling. After both two weeks and one year after trampling, the vegetation reaction was very similar at both research plots.

The mean change was also calculated for individual plant species subjected to the same number of passes at the different altitudes. The supposition that plant cover would be more reduced at the higher altitude proved to be wrong. No unequivocal increase or decrease in the amount of plant cover at the higher altitude was noticed. The mean changes two weeks after trampling ranged from $13 \%$ less plant cover at the higher altitude (Rhodiola fastigiata) to even $25 \%$ more plant cover (Aconogonum rumicifolium). Results after one year confirmed the thesis that there is no dependence (positive or negative) between plant cover and an increase in altitude from $4072 \mathrm{~m}$ to $4480 \mathrm{~m}$ (Table 2). This does not prove, however, that the sensitivity of plants does not increase with altitude. Rather, it indicates that plants above a certain altitude exhibit similar, very high sensitivity to trampling.

\section{Discussion}

Individual plant species varied greatly in their immediate response to trampling and in the amount of recovery that occurred during the year that followed trampling. A strong relationship between the intensity of trampling and changes in plant cover was found two weeks after trampling (see Figure 5). As other experts on the subject have already noted, the interaction between plant cover and trampling is very important $[21,26,29,35]$. After one year, the trend was similar and was also connected to the number of passes and type of vegetation. The scale of damage (loss of vegetation) was much higher after a year than two weeks after trampling, which also corresponds with the results of tests previously carried out in this area. According to the literature, the situation is even worse after a longer period after trampling. For example, after 500 passes, there is no evidence of recovery during the monitoring period, and this continues up to two years after the cessation of trampling [35].

The linear function for the studied population was found to be most appropriate to show the relationship between trampling and vegetation response of the population in question (see Table 1). Hylgaard and Liddle [50] suggested the use of a logistic function, while Cole [21] recommended a second-degree polynomial function. However, several plant species subjected to experimental trampling by Cole [21] also showed a strong linear relationship. It should be noted that in our research some plant species showed the logistic function. However, as the aim of this study was comparative, we looked for a model that would explain the reality in an acceptable way (low $\varphi^{2}$ ) for both heights (M1 and M1) and reading periods (two weeks and one year after trampling).

Due to the fact that each group of plants subjected to a continuous trampling process will consequently be destroyed, it is best to illustrate the relationship between trampling and vegetation response using a linear function. In addition, the linear function, due to its simplicity, is easy to understand and explain. Thus, in the field, the relationship between the number of passes and the scale of damage can be presented to all stakeholders, such as the local population, tour operators, or administration.

The analysis and models used here show diverse, but generally high, correlation rates between trampling intensity and destruction of vegetation cover. This clearly indicates the high destructive potential of trampling and the effectiveness of the selected analysis tool.

Trampling and additional grazing of livestock and pack animals in high mountain valleys undoubtedly affect changes to the flora [20,45]. During the growing season (extremely short in high-mountain areas), the plant must perform the intended vegetation cycle (the entire cycle in the case of annual plants, or a partial cycle in the case of biennial and perennial plants). Disruption of this cycle significantly limits the population, and in some cases can even lead to the plant's extinction. This is important, because in many mountain regions, the growing season coincides with the main tourist season.

This kind of research has an extremely high value [21,32]. It makes it possible to identify species with the highest and lowest trampling resistance. This knowledge may enable regional managers to direct tourism so that it does not lead to the complete elimination of the most sensitive species of 
local flora. In addition, the elimination of more sensitive species may lead to the survival of the more persistent and resistant plants [21]. The consequence may be the modification of the entire ecosystem. Additionally, the introduction (accidental or intentional) of alien, invasive, exotic plant species [51] can contribute to a number of changes and modifications to alpine flora and thus affect other elements of the environment.

\section{Conclusions}

This investigation found that vegetation shows extremely high ecological sensitivity in the examined high-mountain environment. Recreational and tourism activity (trampling) in this environment can lead to serious destruction of vegetation and affect the vegetation cycle. This is important, because in many mountain regions, the growing season coincides with the main tourist season. Moreover, the study demonstrated that a higher altitude does not increase the sensitivity of plants. It indicates rather that plants above a certain altitude exhibit similar, very high sensitivity to destruction. With limited plant resources, high-mountain tourism should make use of those resources very precisely and purposefully.

The main aspect of this study was to question the thesis often believed in tourism and recreation: stress on vegetation resulting from trampling is lower at lower altitudes than at higher ones. In this study, the commonly accepted thesis that vegetation recovers better at lower altitudes than higher ones has failed. However, it needs to be noted that, if the difference in comparable altitudes was higher (not $400 \mathrm{~m}$ as in this study, but, e.g., $800 \mathrm{~m}$ ), the results may be different. Thus, future research into trampling and its environmental impact according to altitude should be continued.

Author Contributions: Conceptualization, M.A.; methodology, M.A.; software, M.A.; formal analysis, M.A. and V.A.; investigation, M.A.; resources, M.A. and V.A.; data curation, M.A.; writing-original draft preparation, M.A. and V.A.; writing-review and editing, M.A. and V.A.; visualization, M.A. and V.A.; project administration, M.A. and V.A. All authors have read and agreed to the published version of the manuscript.

Funding: Funds for this work were provided by the Pedagogical University of Krakow (Poland).

Acknowledgments: We would like to thank Chris Chadwell, Sarah Alexandra Corbet (Department of Zoology, University of Cambridge), Ishwari Datt Rai (Department of Habitat Ecology, Wildlife Institute of India), and the anonymous reviewers for their valuable suggestions and comments. We are also thankful to Marek Zoladek and Phil Varley for their help during field studies. Any mistakes are our own.

Conflicts of Interest: The authors declare no conflict of interest.

\section{References}

1. Meinecke, E.P. A Report on the Effect of Excessive Tourist Travel on the California Redwood Parks; California State Printing Office: Sacramento, CA, USA, 1928.

2. Bates, G.H. The vegetation of footpaths, sidewalks, cart-tracks and gateways. J. Ecol. 1935, 23, 470-487. [CrossRef]

3. Speight, M.C. Outdoor Recreation and Its Ecological Effects: A Bibliography and Review; University College: London, UK, 1973; Volume 4.

4. Dale, D.; Weaver, T. Trampling effects on vegetation of the trail corridors of north Rocky Mountain forests. J. Appl. Ecol. 1974, 11, 767-772. [CrossRef]

5. Cole, D.N. Minimizing conflict between recreation and nature conservation. In Ecology of Greenways: Design and Function of Linear Conservation Areas; Smith, D.S., Hellmund, P.C., Eds.; University of Minnesota Press: Minneapolis, MN, USA, 1993; pp. 105-122.

6. Komárková, V. Alpine Vegetation of the Indian Peaks Area (Front Range, Colorado Rocky Mountains); Flora Veg. Mundi: Vaduz, Liechtenstein, 1979; pp. 1-591.

7. Zachar, D. Soil Erosion; Elsevier: New York, NY, USA, 2011.

8. Tomczyk, A.M.; Ewertowski, M. Quantifying short-term surface changes on recreational trails: The use of topographic surveys and 'digital elevation models of differences' (DODs). Geomorphology 2013, 183, 58-72. [CrossRef] 
9. Tomczyk, A.M.; Ewertowski, M. Planning of recreational trails in protected areas: Application of regression tree analysis and geographic information systems. Appl. Geogr. 2013, 40, 129-139. [CrossRef]

10. Fidelus, J. Slope transformations within tourist footpaths in the northern and southern parts of the Western Tatra Mountains (Poland, Slovakia). Z. Geomorphol. Suppl. Issues 2016, 60, 139-162. [CrossRef]

11. Klug, B.; Scharfetter-Lehrl, G.; Scharfetter, E. Effects of trampling on vegetation above the timberline in the eastern Alps, Austria. Arct. Antarct. Alp. Res. 2002, 34,377-388. [CrossRef]

12. Marion, J.L.; Olive, N. Assessing and Understanding Trail Degradation: Results from Big South Fork National River and Recreational Area. US Geological Survey. 2006. Available online: www.pwrc.usgs.gov (accessed on 10 April 2020).

13. Hill, R.; Pickering, C.M. Differences in resistance of three subtropical vegetation types to experimental trampling. J. Environ. Manag. 2009, 90, 1305-1312. [CrossRef]

14. Apollo, M.; Andreychouk, V. Mountaineering and the natural environment in developing countries: An insight to a comprehensive approach. Int. J. Environ. Stud. 2020,1-12. [CrossRef]

15. Mu, Y.; Nepal, S. High mountain adventure tourism: Trekkers' perceptions of risk and death in Mt. Everest Region, Nepal. Asia Pac. J. Tour. Res. 2015, 21, 500-511. [CrossRef]

16. Apollo, M. The true accessibility of mountaineering: The case of the High Himalaya. J. Outdoor Recreat. Tour. 2017, 17, 29-43. [CrossRef]

17. Apollo, M.; Andreychouk, V.; Moolio, M.; Wengel, Y.; Myga-Piatek, U. Does the altitude of habitat influence residents' attitudes to guests? A new dimension in the residents' attitudes to tourism. J. Outdoor Recreat. Tour. 2020. [CrossRef]

18. Nepal, S.K. Tourism in protected areas: The Nepalese Himalaya. Ann. Tour. Res. 2000, 27, 661-681. [CrossRef]

19. Marek, A.; Wieczorek, M. Tourist traffic in the Aconcagua Massif area. Quaest. Geogr. 2015, 34, 65-76. [CrossRef]

20. Barros, A.; Monz, C.; Pickering, C. Is tourism damaging ecosystems in the Andes? Current knowledge and an agenda for future research. AMBIO 2015, 44, 82-98. [CrossRef] [PubMed]

21. Cole, D.N. Experimental trampling of vegetation. I. Relationship between trampling intensity and vegetation response. J. Appl. Ecol. 1995, 32, 203-214. [CrossRef]

22. Budowski, G. Tourism and conservation: Conflict; co-existence or symbiosis. Environ. Conserv. 1976, 3, $27-31$. [CrossRef]

23. Cole, D.N. Impacts of hiking and camping on soils and vegetation: A review. In Environmental Impacts of Ecotourism: Ecotourism Series; Buckley, R., Ed.; CABI Publishing: New York, NY, USA, 2004; pp. 41-60.

24. Pescott, O.L.; Stewart, G.B. Assessing the impact of human trampling on vegetation: A systematic review and meta-analysis of experimental evidence. PeerJ 2014, 2, e360. [CrossRef]

25. Wagar, J.A. The Carrying Capacity of Wild Lands for Recreation; Society of American Foresters: Washington, DC, USA, 1964.

26. Cole, D.N. Experimental trampling of vegetation. II. Predictors of resistance and resilience. J. Appl. Ecol. 1995, 32, 215-224. [CrossRef]

27. Kycko, M.; Zagajewski, B.; Lavender, S.; Romanowska, E.; Zwijacz-Kozica, M. The impact of tourist traffic on the condition and cell structures of alpine swards. Remote Sens. 2018, 10, 220. [CrossRef]

28. Hertlová, B.; Popelka, O.; Zeidler, M.; Banaš, M. Alpine plant communities responses to simulated mechanical disturbances of tourism, case study from the High Sudetes Mts. J. Landsc. Manag. 2016, 7, 16-21.

29. Cole, D.N.; Bayfield, N.G. Recreational trampling of vegetation: Standard experimental procedures. Biol. Conserv. 1993, 63, 209-215. [CrossRef]

30. Li, Z.; Siemann, E.; Deng, B.; Wang, S.; Gao, Y.; Liu, X.; Zhanga, X.; Guoa, X.; Zhang, L. Soil microbial community responses to soil chemistry modifications in alpine meadows following human trampling. CATENA 2020, 194, 104717. [CrossRef]

31. Willard, B.E.; Cooper, D.J.; Forbes, B.C. Natural regeneration of alpine tundra vegetation after human trampling: A 42-year data set from Rocky Mountain National Park, Colorado, USA. Arct. Antarct. Alp. Res. 2007, 39, 177-183. [CrossRef]

32. Pickering, C.M.; Growcock, A.J. Impacts of experimental trampling on tall alpine herbfields and subalpine grasslands in the Australian Alps. J. Environ. Manag. 2009, 91, 532-540. [CrossRef]

33. Chardon, N.I.; Rixen, C.; Wipf, S.; Doak, D.F. Human trampling disturbance exerts different ecological effects at contrasting elevational range limits. J. Appl. Ecol. 2019, 56, 1389-1399. [CrossRef] 
34. Cole, D.N. Effects of three seasons of experimental trampling on five montane forest communities and a grassland in western Montana, USA. Biol. Conserv. 1987, 40, 219-244. [CrossRef]

35. Whinam, J.; Chilcott, N.M. Impacts after four years of experimental trampling on alpine/sub-alpine environments in western Tasmania. J. Environ. Manag. 2003, 67, 339-351. [CrossRef]

36. Cole, D.N.; Monz, C.A. Trampling disturbance of high-elevation vegetation, Wind River Mountains, Wyoming, USA. Arct. Antarct. Alp. Res. 2002, 34,365-376. [CrossRef]

37. Gallet, S.; Lemauviel, S.; Roze, F. Responses of three heathland shrubs to single or repeated experimental trampling. Environ. Manag. 2004, 33, 821-829. [CrossRef]

38. Gallet, S.; Roze, F. Long-term effects of trampling on Atlantic heathland in Brittany (France): Resilience and tolerance in relation to season and meteorological conditions. Biol. Conserv. 2002, 103, 267-275. [CrossRef]

39. Gallet, S.; Roze, F. Resistance of Atlantic Heathlands to trampling in Brittany (France): Influence of vegetation type, season and weather conditions. Biol. Conserv. 2001, 97, 189-198. [CrossRef]

40. Liddle, M.J. A theoretical relationship between the primary productivity of vegetation and its ability to tolerate trampling. Biol. Conserv. 1975, 8, 251-255. [CrossRef]

41. Talbot, L.M.; Turton, S.M.; Graham, A.W. Trampling resistance of tropical rainforest soils and vegetation in the wet tropics of north east Australia. J. Environ. Manag. 2003, 69, 63-69. [CrossRef]

42. Humboldt, A. Ideen zu Einer Geographie der Pflanzen Nebst Einem Naturgemälde der Tropenländer; Cotta: Tübingen, Germany, 1807.

43. Darwin, C. On the Origin of the Species by Means of Natural Selection; Murray: London, UK, 1859.

44. Kulkarni, A.V.; Rathore, B.P.; Singh, S.K.; Bahuguna, I.M. Understanding changes in the Himalayan cryosphere using remote sensing techniques. Int. J. Remote Sens. 2002, 32, 601-615. [CrossRef]

45. Apollo, M.; Andreychouk, V.; Bhattarai, S.S. Short-term impacts of livestock grazing on vegetation and track formation in a high mountain environment: A case study from the Himalayan Miyar Valley (India). Sustainability 2018, 10, 951. [CrossRef]

46. Saini, R. Glacier Dynamics Water Resource Assessment and Landscape Evolution in Miyar Basin, Lahaul Himalayas, Himachal Pradesh. Ph.D. Thesis, Jawaharlal Nehru University, New Delhi, India, 2008.

47. Apollo, M. The clash-social, environmental and economical changes in tourism destination areas caused by tourism the case of Himalayan villages (India and Nepal). Curr. Issues Tour. Res. 2015, 5, 6-19.

48. Zoladek, M.; Kordowska, M. Exploration tourism: Based on selected areas. In Contemporary Studies in Environment and Tourism; Efe, R., Öztürk, M., Eds.; Cambridge Scholars Publishing: Newcastle upon Tyne, UK, 2017; pp. 1-8.

49. Polunin, O.; Stainton, A. Flowers of the Himalaya; Oxford University Press: New Delhi, India, 2011.

50. Hylgaard, T.; Liddle, M.J. The effect of human trampling on a sand dune ecosystem dominated by Empetrum nigrum. J. Appl. Ecol. 1981, 18, 559-569. [CrossRef]

51. Barros, A.; Pickering, C.M. Non-native plant invasion in relation to tourism use of Aconcagua Park, Argentina, the highest protected area in the Southern Hemisphere. Mt. Res. Dev. 2014, 34, 13-26. [CrossRef]

(C) 2020 by the authors. Licensee MDPI, Basel, Switzerland. This article is an open access article distributed under the terms and conditions of the Creative Commons Attribution (CC BY) license (http://creativecommons.org/licenses/by/4.0/). 